[14] Kopytchuk I.N., Tishin P.M. Modeli, metody i informationnaia technologia povishenia tochnosti registracii massi dvishuchihsia grysov v tenzometricheskih sistemah. Odessa. pp. 35-46, 2016.

[15] Borisov V.V., Kruglov V.V., Fedulov A.S. Nechetkie modeli I seti. Telecom. pp. 218-230, 2007.

УДК 621.867.2

\title{
РОЛИКОВИЙ ВУЗОЛ СТРІЧКОВОГО ТРАНСПОРТЕРА
}

\author{
Сандлер А.К. ${ }^{1}$, Дрозд О.В. ${ }^{2}$ \\ 1,2 - Національний університет "Одеська морська академія", м. Одеса, Україна \\ E-mail: ${ }^{1}$ albertsand4@gmail.com, ${ }^{2}$ ELENADROZD912@gmail.com
}

Copyright (C) 2018 by author and the journal “Automation technologies and business - processes. This work is licensed under the Creative Commons Attribution International License (CC BY). http://creativecommons.org/licanses/by/4.0

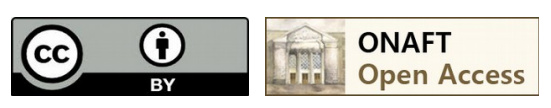

DOI: $10.15673 /$ atbp.v10i4.1237

Анотація: Розглянуті відомі конструкцї роликових опор стрічкових транспортерів, як елементу вантажної системи судна. Визначені недоліки та шляхи вдосконалення. Запропоновано нове схемотехнічне рішення роликової опори.

Summary: Considered known designs of roller bearings of belt conveyors, as an element of the ship's cargo system. Deficiencies and ways to improve. A new circuit design of roller support is proposed.

Ключові слова: судновий стрічковий конвеєр, стрічка, ролик, експлуатація, ремонт, обслуговування.

Keywords: ship conveyor belt, belt, roller, operation, repair, service.

\section{1. Вступ}

Багаторічний досвід експлуатації транспортерів підтверджує головні до-стоінства конвеєрного транспорту високий рівень продуктивності праці, що досягається шляхом автоматизації роботи устаткування, можливість транспортування вантажу на великі відстані і низькі виробничі витрати. Вони є одним 3 основних засобів безперервного дільничного і магістрального транспорту в морських портах, на вугільних шахтах, розрізах і рудниках. Застосування стрічкових трансполртерів постійно зростає в зв'язку 3 ростом вантажопотоків і відстаней транспортування, що зумовило необходідність створення високопродуктивних стрічкових транспортерів більшої довжини і потужності (рис. 1).

Досить високі капітальні витрати на придбання транспортерів компенсуються низькими експлуатаційними витратами. Собівартість одиниці вантажу, що перевозиться стрічковими транспортерами нижче, ніж у інших транспортних засобів, що застосовуються для перевезень вантажу на ту ж відстань. 


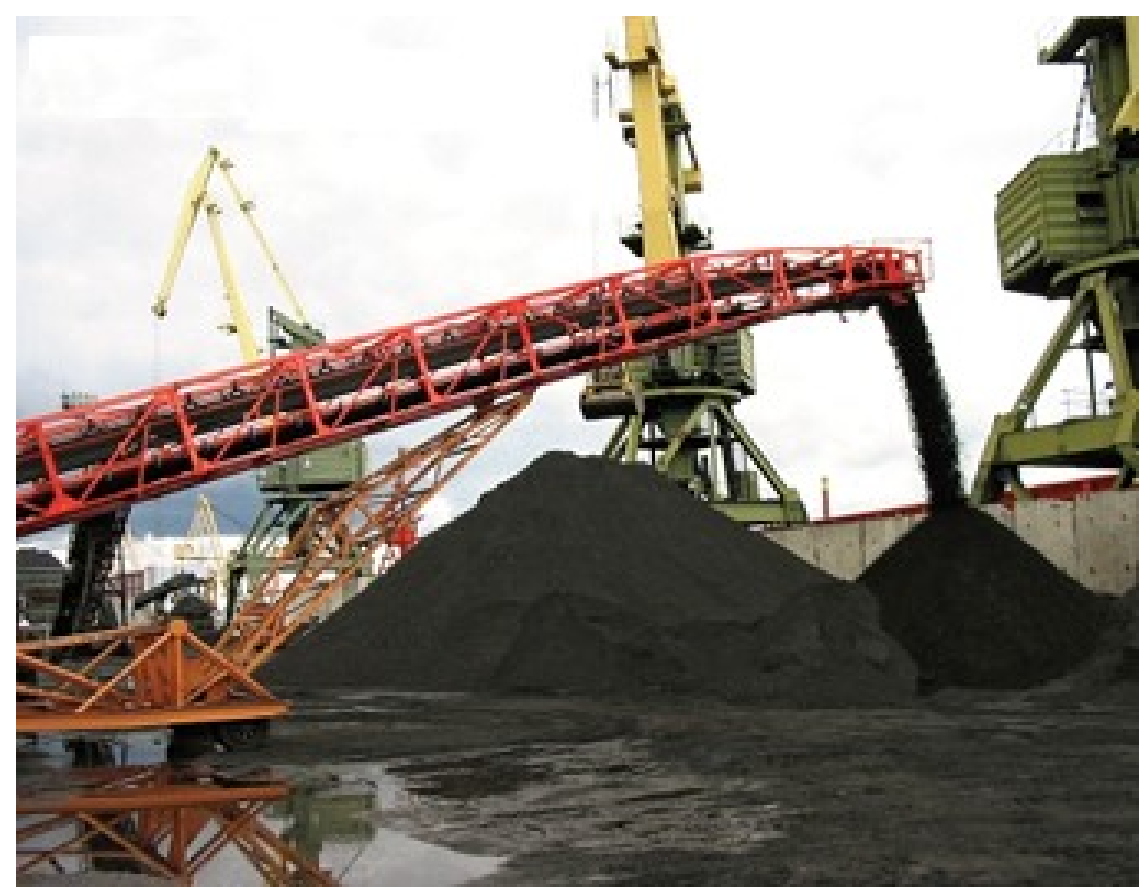

Рис. 1 - Найпоширеніший тип стрічкового транспортеру

\section{2. Аналіз літературних джерел і постановка питання}

Практика використання традиційних стрічкових транспортерів різноманітного призначення, виконання i типорозмірів показує, що всім без виключення, пристроям притаманний невикорінний принциповий недолік - знос роликів і зміщенням стрічки. Періодичні підйоми і опускання ділянок стрічки та лежачого на ній вантажу призводять до появи динамічних навантажень, ще більшого зниження терміну служби стрічки і роликів, а також суттєвого зростання енергоємності процесу транспортування. Ці процеси призводять до передчасного виходу стрічки з ладу, зсуву вантажу, дроблення, пилення і втрати його якості при транспортуванні [1].

Для пошуку шляхів підвищення терміну служби стрічки і роликів проаналізовані конструкції найпоширеніших роликових вузлів стрічкових транспортерів [2 - 4].

Відомий роликовий вузол, що містить основу та ролики з підшипниками ковзання [2].

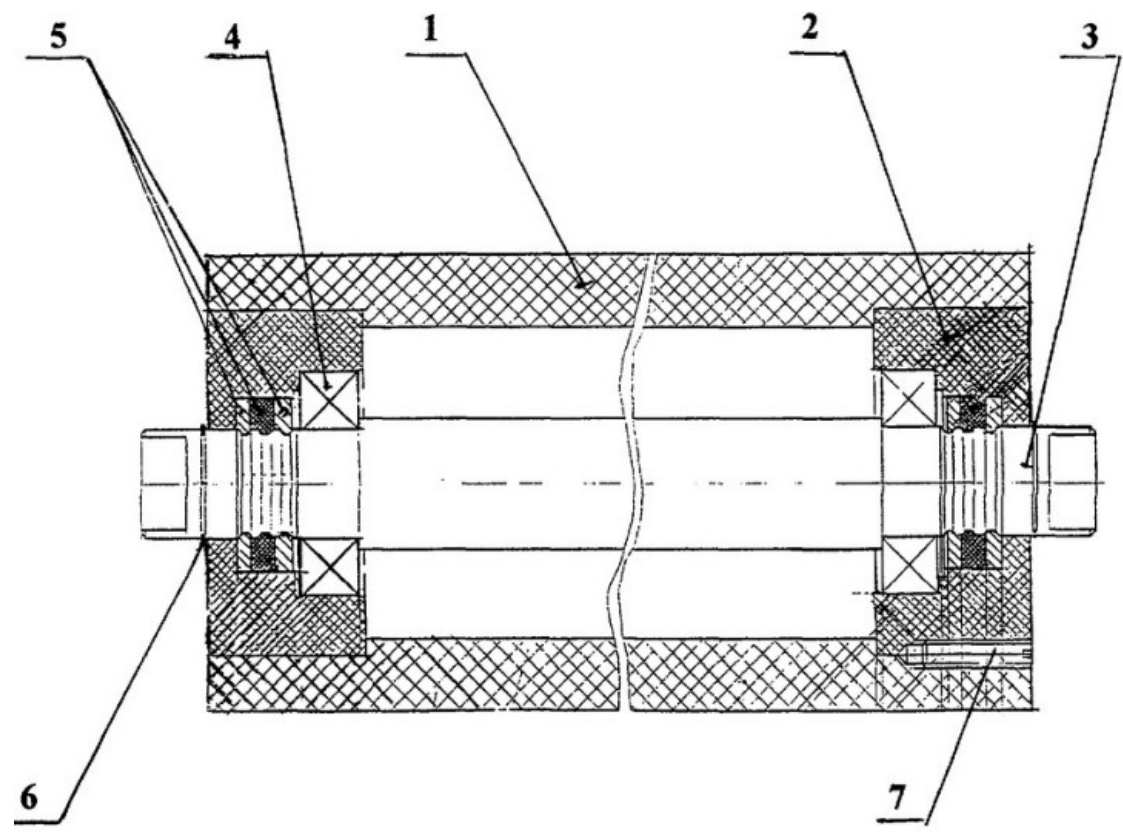

Рис. 2 - Ролик 3 підшипником ковзання: 1 - корпус; 2 - стакани; 3 - вісь ролика; 4 - підшипники ковзання; 5 ущільнювальні кільця; 6 - стопорні кільця; 7 - штифти. 
Недоліки пристрою, які обумовлені застосуванням сталевого ролика та підшипників ковзання:

- необхідність постійного оновлення змащувального матеріалу підшипника;

- незахищеність роликового вузла від динамічних ударів вантажу на стрічці та експлуатаційних факторів;

- $\quad$ значні витрати на ремонтні роботи.

У меншій мірі експлуатаційні та конструктивні фактори впливають на характеристики роликового вузла, що містить основу та ролики з підшипниками кочення [3].

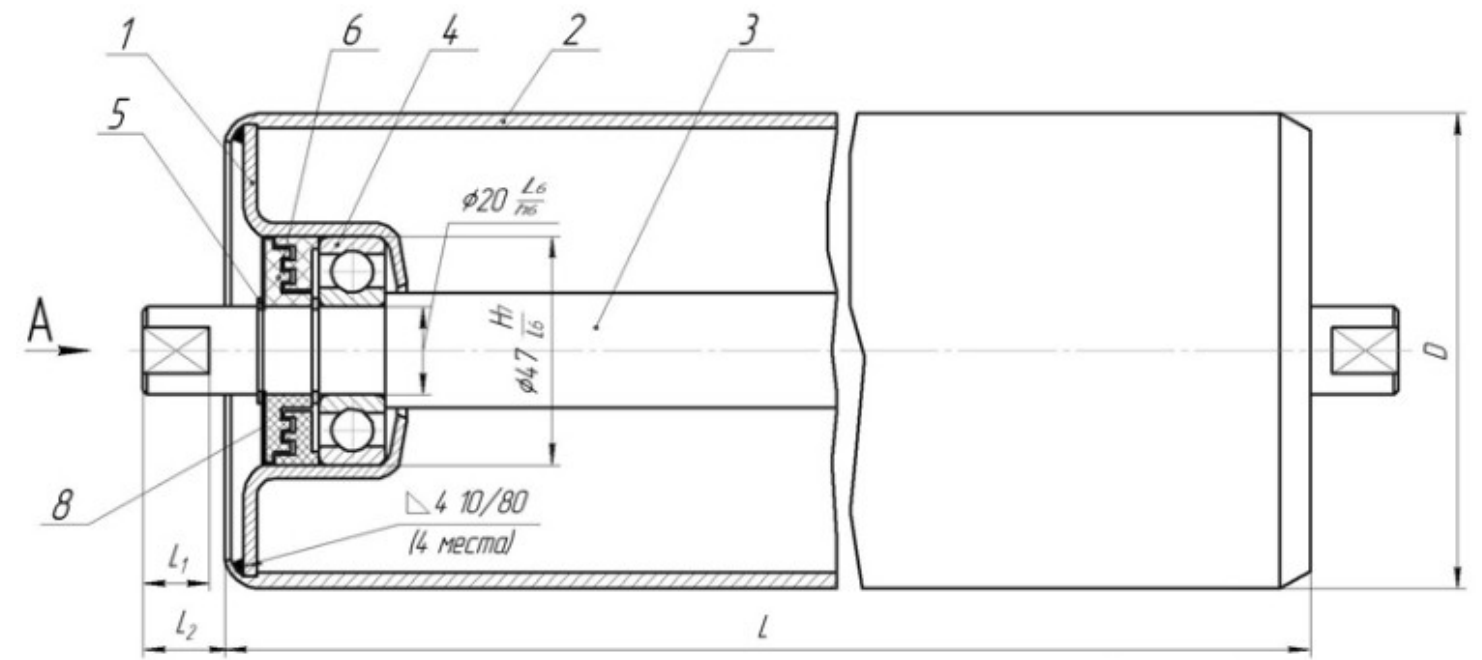

Рис. 3 - Ролик 3 підшипником кочення: 1 - обойма; 2 - корпус; 3 - вісь ролика; 4 - підшипники кочення; 5 стопорне кільце; 6-8 - ущільнювальні кільця.

Недоліки пристрою, які обумовлені застосуванням відкритого сталевого ролика та підшипників кочення:

- незахищеність роликового вузла від динамічних ударів вантажу на стрічці та експлуатаційних факторів;

- неможливість транспортування вантажу у вигляді великих фрагментів;

- значні витрати на ремонтні роботи.

3. Мета і задачі дослідження

В умовах, що склалися, доцільною стала розробка нового схемотехнічного рішення роликового вузла. Передбачалося, що конструктивне виконання повинне забезпечити пристрою:

- можливість застосовування у транспортерах для транспортування великих фрагментів вантажу;

- присутність демпфірування динамічних ударів вантажу по роликах;

- підвищену зносостійкість самих роликів;

- зниження експлуатаційних та ремонтних витрат;

- збереження простоти схемотехнічних рішень роликових вузлів відомих типів.

4. Основні пункти та результати дослідження

Суть схемотехнічного рішення пояснюється кресленням (рис. 3).

Шліцьова втулка запресована до основи і взаємодіє з торсіонним валом завдяки відповідним шліцам на ньому.

При надходженні ділянки транспортерної стрічки з вантажем до відповідного ролика динамічне навантаження 3 ролика крізь стойки передається до торсіонного валу. Під впливом навантаження відбувається деформація кручення валу. Завдяки пружнім деформаціям валу відбувається гасіння та демпфіруванням коливань транспортеру [5].

Для здійснення винаходу застосовано комбінацію механічних елементів.

У першому динамічному режимі (транспортування вантажу у вигляді малих фрагментів) демпфірування динамічних навантажень на основу та підшипники роликового вузла відбувається за рахунок пружних деформацій торсіонного валу. Зниження зносу транспортерної стрічки відбувається за рахунок використання армованого гумового чохла ролика.

У другому динамічному режимі (транспортування вантажу у вигляді великих фрагментів) демпфірування динамічних навантажень на основу та підшипники роликового вузла відбувається за рахунок пружних деформацій як торсіонного валу так і дії гумових амортизаторів. Зниження зносу транспортерної стрічки відбувається за рахунок використання армованого гумового чохла ролика.

Запропоноване схемотехнічне рішення відрізняється тим, що ролик 3 підшипниками закріплений на стойках, з`днаних $з$ торсіонним валом, який зафіксований у шліцьовій втулці основи, ролик вкрито роз ємним армованим гумовим чохлом, а стойки мають гумові амортизатори [5, 6, 7]. 


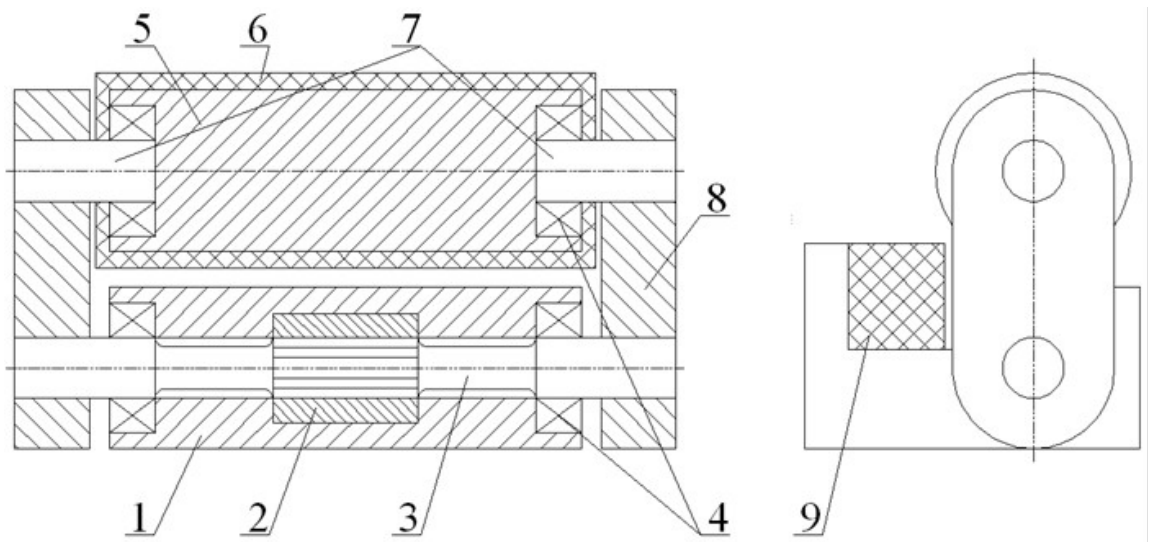

Рис. 4 - Роликовий вузол стрічкового транспортера: 1 - основа; 2 - шліцьова втулка; 3 - торсіонний вал; 4 підшипники кочення; 5 - ролик; 6 - армований гумовий чохол; 7 - вісь ролика; 8 - стойка; 9 - гумовий амортизатор.

\section{5. Висновки}

Таким чином, в розробленому вузлу комбінація пружних елементів та підшипників забезпечує:

- підвищення продуктивності транспортерів;

- можливість транспортування великих фрагментів матеріалів;

- відсутність зсуву транспортерної стрічки;

- демпфірування динамічних навантажень на роликовий вузол;

- підвищення терміну служби роликових вузлів та транспортерної стрічки;

- $\quad$ зниження експлуатаційних та ремонтних витрат.

Застосування запропонованої моделі роликового вузла, крім того, дозволить підвищити безпеку і ефективність вантажних технологічних процесів при роботі з широким спектром вантажів.

\section{Список використаних джерел}

[1] Ивченко, В.Н. Куров, С.В. Беспросыпные ленточные конвейеры.// Горная Промышленность. - $2005 .-$ № 4.

[2] Конвейеры: Справочник / Р. А. Волков, А. Н, Гнутов, В. К. Дьячков и др. Под общ. ред. Ю. А. Пертена. - Л.; Машиностроение, 1984. - 367 с.

[3] Зелинский, О.В., Петров А.С. Справочник по проектированию ленточных конвейеров. - М.: Машиностроение, 1986. -500 c.

[4] Чобиток, В.М. Ходовая часть танков. Подвеска. //Техника и Вооружение. - 2005. - №11.

[5] Сергеев, Л.В. Теория танка. - М.: Военная ордена Ленина Краснознаменная академия бронетанковых войск им. маршала Малиновского, 1973. - 490 с.

[6] Лобанов, Н.В. Моделирование торсионной подвески гусеничных транспортных средств.// Вестник РГРТУ. 2008. - вып. 23.

[7] Сандлер, А.К., Дрозд, О.В. Роликовий вузол стрічкового транспортера. Деклараційний патент України № 118311. МПК (2017.01) G 01G 11/10 (2006.01), G01G 21/06 (2006.01), В65G 39/00 - заявл. 03.05.2017. // Опубл. 25.07.2017, бюл. № 14/2017.

\section{References}

[1] Ivchenko, V.N. Kurov, S.V. Besprosypnyye lentochnyye konveyyery.// Gor-naya Promyshlennost'. - 2005 . - № 4.

[2] 2. Konveyyery: Spravochnik / R. A. Volkov, A. N, Gnutov, V. K. D'yachkov i dr. Pod obshch. red. YU. A. Pertena. L.; Mashinostroyeniye, 1984. - 367 s.

[3] 3. Zelinskiy, O.V., Petrov A.S. Spravochnik po proyektirovaniyu lentoch-nykh konveyyerov. - M.: Mashinostroyeniye, 1986. $-500 \mathrm{~s}$

[4] 4. Chobitok, V.M. Khodovaya chast' tankov. Podveska. //Tekhnika i Vooruzhe-niye. - 2005. - №11.

[5] 5. Sergeyev, L.V. Teoriya tanka. - M.: Voyennaya ordena Lenina Krasnozna-mennaya akademiya bronetankovykh voysk im. marshala Malinovskogo, 1973. - 490 s.

[6] 6. Lobanov, N.V. Modelirovaniye torsionnoy podveski gusenichnykh transportnykh sredstv.// Vestnik RGRTU. - 2008. - vyp. 23.

[7] 7. Sandler, A.K., Drozd, O.V. Rolikoviy vuzol stríchkovogo transportera. Deklaratsíyniy patent Ukraîni № 118311. MPK (2017.01) G 01G 11/10 (2006.01), G01G 21/06 (2006.01), B65G 39/00 - zayavl. 03.05.2017. // Opubl. 25.07.2017, byul. № 14/2017. 